\title{
INCLUSIVE TOLERANCE AS A BASIS OF PROFESSIONAL COMPETENCE OF PROSPECTIVE TEACHERS
}

\author{
Vera V. Khitruk, Olga A. Ulianova \\ Baranovichi State University, Belarus \\ E-mail: hvv64@tut.by, ulianova@tut.by
}

\begin{abstract}
The article describes the results of the comparative analysis of tolerance as a basis of professional competence of prospective teachers, whose professional activity can be carried out under the conditions of educational integration or/and inclusive education. The research purpose is to study tolerance among first-year and senior pedagogues, which makes it possible to discuss determinacy of the formation process of inclusive tolerance by the content of pedagogical education in the comparative (the first-year and senior students of the department of pedagogy) aspect.

The study of inclusive tolerance of prospective teachers has been carried out using a set of standardized methods adapted to the conditions of the research purpose. Thus, the stimulus material of the methods included the questions among many others the answers to which implied the expression of attitudes towards children/persons with special needs.

The obtained results show, that the actual formation level of inclusive tolerance of the students of pedagogical specializations do not permit to determine their professional competence as sufficient in professional realization under the conditions of inclusive education. The paradoxicality of the obtained results consists in the fact, that in general the indices characterizing the formation level of inclusive tolerance decrease from the first to final years. This fact enables to state, that the content of pedagogical education does not have strong enough influence on the formation of this professional quality.

Key words: children with special needs, inclusive education, inclusive tolerance, integrated education and upbringing.
\end{abstract}

\section{Introduction}

The process of educational integrity of children with special needs and a gradual transition to inclusive education is a topical issue under discussion in many countries. This requires reconsideration generally accepted stands towards all participants of the educational process and his/her preparation to work under the new conditions in all senses. Unfortunately, it becomes evident, that a pedagogue is not always ready to show tolerance and interact with "other" participants of the educational process on a tolerant basis. Once under the conditions of educational integration, a pedagogue may experience both confusion and difficulties in his/her work with children with special needs and is not able to take into account the individual features of their development in the educational process, interaction with other educational subjects, parents of both children with no disabilities and those with special needs.

Tolerance is conventionally viewed as: acceptance of the individuality of another person and of one's own personality, the ability to understand emotional states of other persons, the urge to dialog and cooperate in interaction, refusal of dominance and violence (Zmushko, 2010); readiness to accept different opinions and logics, the right to be different, dissimilar, uncommon (Kasianova, 2009); a value, attitude and personal quality as a stabilizing factor of the system 
PROBLEMS

OF EDUCATION

IN THE $21^{\text {st }}$ CENTURY

Volume 43, 2012

22

(Streltsova, 2004); a complex multiple-aspect construct, which includes personal, emotional, cognitive, behavioral components and psychophysical premises (Gershunskyi, 2002).

The social-philosophical interpretation of tolerance views the essence of the notion as tolerance displayed by a social subject towards political, ethnic and other peculiarities of another social subject (Kasianova, 2009). This implies the orientation to certain value systems, which permits to discuss the ethical basis of tolerance - moral terms, norms, rules, values, as well as the mechanism of their inclusion in the regulation process of tolerant behaviors (Krivtsova, 2009; Sokolov, 2003). It should not be forgotten, that the tolerance phenomenon is subject-objectively oriented and can be manifested selectively.

The analysis of the research studies on this topic has shown its multi-faceted and multipleaspectual character in different scientific fields: philosophical, political, culturological, juridical, sociological, physiological. A keen interest in this issue can be seen in the psychologicalpedagogical research studies: general pedagogical issues of tolerance, formation conditions of tolerance as a significant professional quality (Astashkova, 2002; Baiborodova, 2001; Gracheva, 2009; Zhelnovich, 2010; Morgunova, 2009; Nikolaeva, 2007; Panina, 2005; Pogodina, 2006), certain methods and ways of tolerance formation. The aspects of the formation level of tolerance of future pedagogues towards children with special needs as an important professional quality, which ensures efficiency under the conditions of educational integration or inclusive education, remain uninvestigated. Special features of the subject, with respect to which the studied phenomenon emerges, allows us to define it as "inclusive tolerance", i.e. a professionalpsychological quality of a pedagogue which defines a certain way of communication and interaction with "different" children under the conditions of educational integration (inclusive education) and ensures his/her professional competence.

Pedagogical competence can be considered as an integral characteristic of personal qualities based on the system of knowledge, skills, ways of performance of professionalpedagogical activity, which help to solve practical tasks of education, upbringing, and development of a personality and social adaptation of a child with special needs (Gladkaya, 2011). The structure of competence of prospective teachers, whose professional realization takes place under the conditions of educational integration (inclusive education), consists of the following components:

- Social-legal - knowledge and skills in the process of interaction with public institutions and people, methods of professional communication and behaviour;

- Special (informative-methodical, technological) - readiness to perform pedagogical activities under the conditions of educational integration (inclusive education);

- Motivational-empathic - orientation of a pedagogue's personality towards a tolerant attitude to every child, creation of organizational, psychological-pedagogical conditions ensuring the development of a personality, emotional comfort and welfare of a child with special needs, his/her adequate pedagogical interaction with other children with no health problems and pedagogues.

Ontology researchers consider the educational content as the formation conditions of tolerance: teaching organization of the cycle of humanitarian subjects which content, if an emphasis is made on certain things, can significantly influence the formation process of tolerance, introduction of optional subjects on tolerance. Other mentioned conditions are organization and holding of special games and trainings.

Tolerance is an important component of professionalism as well as reflexivity and empathy, as it has a humanitarian function of the formation of value orientations and interests of prospective teachers.

All the above mentioned gives reasons to consider in detail, study and accept the 
phenomenon, as well as to prepare would-be pedagogues to work under new educational conditions in the future.

The topicality of this research is based on the contradiction between, on the one hand, the necessity of the society to fulfil the principle of tolerance in practice by pedagogues, the modern requirements to the character and content of the pedagogical activity, the personalities of pedagogues under the conditions of educational integration (inclusive education) and, on the other hand, insufficient theoretical and methodological material on the issues for its study.

\section{Problem of Research}

Tolerance as a personal quality has a subjective-objective orientation: emerges and forms towards a subject. A child with special needs is a subject whose individuality should be accepted and taken into consideration in the work under the conditions of inclusive education. It can be guaranteed by a high formation level of tolerance as a personal quality. In this connection, the purpose of this research is to reveal the formation level of inclusive tolerance of prospective teachers. The essence of the research problem is the answer to the questions: What formation level of inclusive tolerance do first-year and senior students have? How tolerant are prospective pedagogues towards children with special needs with whom they will have to work under the conditions of integrated education (inclusive education)? Does the content of pedagogical education influence the formation process of inclusive tolerance?

\section{Research Focus}

The main issue studied in the research is the influence of the content of pedagogical education on the formation of a tolerant attitude of prospective teachers towards children with special needs (inclusive tolerance). The studied issue is of a great interest for practical use of the obtained results in the educational process of preparation of prospective teachers.

\section{Methodology of Research}

\section{General Background of Research}

When defining the diagnostic tools adequate to the research purpose, we took into consideration such basic aspects of the studied phenomenon as: 1) tolerance as a psychological stability 2) tolerance as a set of positive attitudes 3 ) tolerance as a range of individual qualities 4) tolerance as a set of personal and group values (Soldatova, 2008).

Tolerance as a psychological stability is viewed as a person's special feature to resist external impacts which affect the neuropsychic balance of the person and the ability to restore the state of the neuropsychic balance quite quickly.

The social-physiological stability implies the stability towards the world's diversity, social, cultural and world-views differences. It is expressed through the system of social attitudes and value orientations. This tolerance aspect is the basis of empathy, altruism, peacefulness, trust, moral, sociability, cooperation, etc.

To define the criteria and levels of tolerance in our research the opinion of Lectorskyi (1997) is taken as a basis, who admits the existence of different tolerance levels and underlines the multi-faceted character of this notion: 1) "tolerance" as indifference to the existence of different opinions which can never prove to be true. Tolerance is viewed as indifference to the existence of different views and opinions viewed as "unimportant in front of the main problems which the society has to face" 2) "tolerance as mutual understanding" limits indulgence and 
PROBLEMS

OF EDUCATION

IN THE $21^{\text {st }}$ CENTURY

Volume 43,2012

respect towards another person who cannot be understood or dealt with 3) "tolerance as indulgence" is considered as a privileged position of one's culture, so all other cultures are viewed as unworthy of attention. They can be understood, tolerated and despised at the same time 4) "tolerance as broadening of one's experience and a critical dialogue" enables not only to respect a different opinion but to change one's opinion as a result of a critical dialogue (Pchelintseva, 2006; Tarantei, 2011).

The last interpretation of the notion enables to materialize the idea of tolerance as the formation purpose of a tolerant person in the preparation process of a prospective pedagogue ready to work under the conditions of educational integration, and gives reasons to define the following criteria of the formation level of tolerance:

1) psychophysical stability, set of positive attitudes, the range of individual qualities, level of social trust;

2) set of positive attitudes, values and orientations of a person which depict the degree of a positive attitude towards the world's diversity, social, cultural and other differences;

3) level of xenophobia viewed as hostility, animosity and fear of those persons and groups of people who are not similar to us. Its psychological function is to protect, its purpose is to isolate either fully or partially. The xenophobia level is determined through the set of attitudes and values which depict the state "We -or-They" or "Friend-or-Foe".

\section{Sample of Research}

The first-year and senior students of the specializations of the pedagogical department took part in the empirical studies conducted on the basis of the Baranovichi State University, "Primary education. The Belarusian language and literature", "Technology (service work). Social pedagogy", "Preschool education. Practical psychology", "Primary education. Physical education", "Practical psychology. Technology (service work)". The sampling made 318 persons, including 166 first-year and 152 senior students at the age of 18-23. All participants were divided into two groups (independent samplings): 1) first-year students 2) senior students. Both the general sampling and the samplings of each group are representative and homogenous (according to age, gender, level of education, profession).

\section{Instrument and Procedures}

The program of diagnostics of tolerance to children with special needs included the complex of standardized diagnostic methods (three blocks), the estimation levels of formation of the mentioned features, that permitted to get reliable results and exclude the subjective factor. The first block consists of the methods which determine the general propensity for tolerant behaviour: "Eysenck questionnaire", the express questionnaire "Tolerance index" (Soldatova, 2008). The second block includes the diagnostic methods of the content component of tolerance: the affiliation questionnaire (behavioural motives), the diagnostic methods of general communicative tolerance (Soldatova, 2008). The third block consists of the methods to study the attitudes of prospective pedagogues towards children with special needs: Eurobarometer (research on xenophobia), "The scale of social distance" (Soldatova, 2008). The adaptation of the stimulated materials of the standardized methods included the material (questions, statements, etc.) about children (persons) with special needs.

The first block methods: the standardized methods "Eysenck questionnaire" helped to reveal: the propensity of the students of pedagogical specializations for specific behaviour in dealing with different people regardless of their social-psychological peculiarities: the ability to control one's emotions, thoughts, behaviour, mental state which is responsible for positive attitudes to other people in interaction processes. 
The stimulated material of the methods of the express questionnaire "Tolerance index" include the statements which depict both the general attitude to the world and other people and social attitudes in different fields of interaction. The methods also include the statements depicting attitudes to certain social groups and communicative attitudes. Special attention was paid to the attitudes to children (persons) with special needs (instead of an ethnic group or another race).

The second block methods: the methods of the affiliation questionnaire are aimed at studying the formation of professionally important personal qualities, behavioural motives, satisfaction degree in communication with other people.

The diagnostic methods of general communicative tolerance are aimed at studying the person's abilities to establish positive relations with other people and the world on the whole. The level of situational tolerance is determined by the attitude of this person towards his/her interlocutor; typological tolerance $\backslash$ is determined by the attitude towards a generalized group or type of people (in our case towards children with special needs). Professional tolerance in interaction is displayed towards those, who a person has to deal with at his/her job. General communicative tolerance is based on life experience, features of the character, moral principles, and predetermines to a large extent other forms of tolerance in the society.

The third block methods: "the social distance scale" is one of the most famous diagnostic methods of tolerance as a set of attitudes and values, authoritarianism degree, social and other prejudices and enables to measure the degree of social distance towards the representatives of different social groups, tolerance of a person to cultural, ethnic, religious, social and other differences (the degree of closeness or alienation between two groups of people including the groups of future pedagogues and children with special needs).

The methods consist of social indicators (standard stimuli-questions which, when answered, show revealing reactions of the respondents which indicate the absence/presence of a studied quality, feature or process) which enable to determine the xenophobia level (fear, rejection to accept a "difference").

The research was being conducted from 2010 to 2012 at several stages: the collection of empiric data using diagnostic methods in the pedagogical groups of the first-year students (2010), the content analysis of the State standards of preparation of pedagogues (2011), the collection of empiric data using diagnostic methods in the pedagogical groups of the senior students (2011), the analysis and description of the obtained data (2012). The stimulus material of the diagnostic methods was given simultaneously to each respondent.

\section{Data Analysis}

The outlined parameters can be formed at different levels and enable to create the whole picture of inclusive tolerance of prospective pedagogues (see Table 1). 
PROBLEMS

OF EDUCATION

IN THE $21^{\text {st }}$ CENTURY

Volume 43,2012

Table 1. The description of the formation levels of the studied levels of inclusive tolerance of prospective pedagogues.

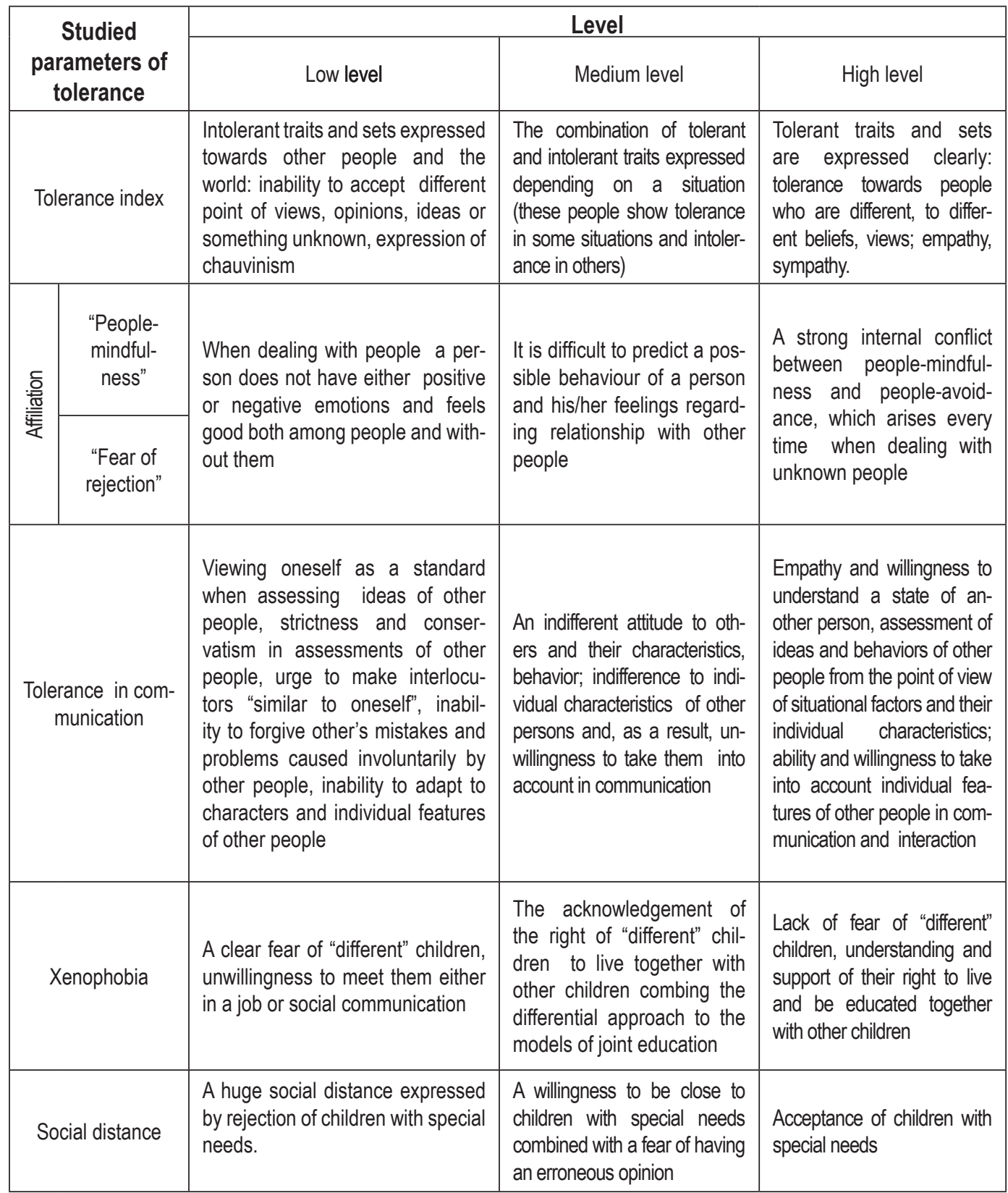

\section{Results of Research}

The analysis of the results was carried out using the comparative method (the firstyear and senior students). These results characterize the division of the respondents by types of personality (the methods "G. Eysenck questionnaire") (see Table 2). 
Table 2. The representativeness of personalities types in the groups of the firstyear and senior students.

\begin{tabular}{|c|c|c|c|c|c|c|c|c|}
\hline & \multirow[b]{2}{*}{$n$} & \multicolumn{2}{|c|}{ Stable type } & \multicolumn{2}{|c|}{ Neurotic type } & \multirow[b]{2}{*}{$\begin{array}{l}\grave{\Phi} \\
\sum_{0} \\
\stackrel{0}{\pi} \\
0 \\
2\end{array}$} & \multirow[b]{2}{*}{$\chi^{2}$} & \multirow[b]{2}{*}{$\begin{array}{c}\text { Critical value } \\
\chi^{2} \\
(p<0.05)\end{array}$} \\
\hline & & 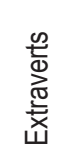 & 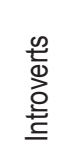 & 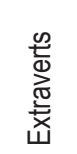 & 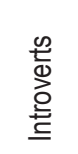 & & & \\
\hline $\begin{array}{l}\text { First year stu- } \\
\text { dents }\end{array}$ & 166 & 4.9 & 1.2 & 72.7 & 20.5 & 0.6 & \multirow[t]{2}{*}{6.58} & \multirow[t]{2}{*}{9.49} \\
\hline Senior students & 152 & 2.0 & 3.3 & 70.3 & 23.1 & 1.3 & & \\
\hline
\end{tabular}

The results in the table show the absence of statistically significant differences in the demonstration of stability/neuroticism and extraversion/ introversion in the pedagogical groups of the first-year and senior students.

The use of diagnostic tools enables to get the whole idea about the formation level of the inclusive tolerance parameters of the first-year and senior students (see Table 3), as well as to establish the presence/absence of statistically significant differences between two empirical subgroups.

Table 3. The contrastive analysis of the formation of the inclusive tolerance parameters of the first-year and senior students.

\begin{tabular}{|c|c|c|c|c|c|c|c|c|c|}
\hline \multirow{3}{*}{\multicolumn{2}{|c|}{$\begin{array}{l}\text { Studied parameters of toler- } \\
\text { ance }\end{array}$}} & \multicolumn{6}{|c|}{ Level (\%) } & \multirow[b]{3}{*}{$\chi^{2}$} & \multirow{3}{*}{ 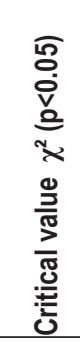 } \\
\hline & & \multicolumn{2}{|c|}{ Low level } & \multicolumn{2}{|c|}{ Medium level } & \multicolumn{2}{|c|}{ High level } & & \\
\hline & & 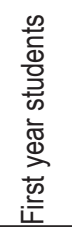 & 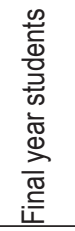 & 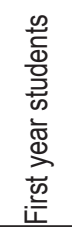 & 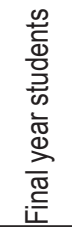 & 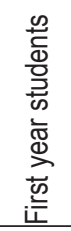 & 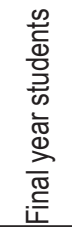 & & \\
\hline \multicolumn{2}{|c|}{ Tolerance index } & 0.6 & 1.4 & 88.0 & 92.6 & 11.4 & 6.0 & 3.87 & 5.99 \\
\hline \multirow{2}{*}{ Affiliation } & $\begin{array}{l}\text { "People- } \\
\text { mindfulness" }\end{array}$ & 0.6 & 1.3 & 98.8 & 98.7 & - & - & 0.81 & 5.99 \\
\hline & $\begin{array}{l}\text { "Fear of } \\
\text { rejection" }\end{array}$ & 0.6 & 2.0 & 97.6 & 98.0 & 0.6 & - & 0.81 & 5.99 \\
\hline \multicolumn{2}{|c|}{$\begin{array}{l}\text { Tolerance in the communica- } \\
\text { tions }\end{array}$} & - & - & 42.4 & 53.7 & 57.6 & 46.3 & 5.22 & 5.99 \\
\hline \multicolumn{2}{|c|}{ Xenophobia } & 34.8 & 20.8 & 25.5 & 32.9 & 27.3 & 30.2 & 12.4 & $13.82^{*}$ \\
\hline \multicolumn{2}{|c|}{ Social distance } & 3.2 & 5.2 & 17.9 & 21.9 & 78.9 & 72.9 & 2.59 & 5.99 \\
\hline
\end{tabular}

$* \mathrm{p}<0.001$

The comparative results of quantitative indices of the outlined parameters of inclusive tolerance in the groups of the first-year and senior students are shown in Figures $1-4$. 
PROBLEMS OF EDUCATION IN THE $21^{\text {st }}$ CENTURY Volume 43, 2012
- First Final

92,6

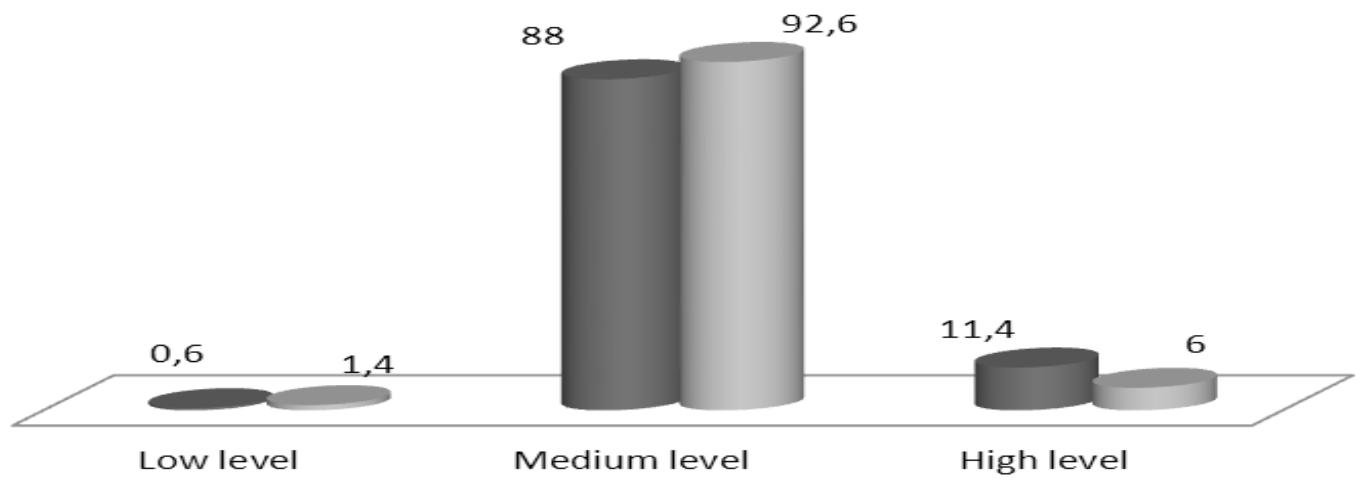

Figure 1: The comparative analysis of the tolerance level displayed by the firstyear and senior students of the pedagogical specializations.

And the character of the answers of the first-year and senior students to the questions regarding people with special needs is bewildering (see Table 4).

Table 4. The comparative analysis of the revealing character of inclusive tolerance of the first year and senior students.

\begin{tabular}{|c|c|c|c|c|c|c|c|c|c|c|c|}
\hline \multirow[b]{2}{*}{ № } & \multirow[b]{2}{*}{ Statements } & & \multicolumn{7}{|c|}{ Students' answers (\%) } & \multirow[b]{2}{*}{$\chi^{2}$} & \multirow[b]{2}{*}{ 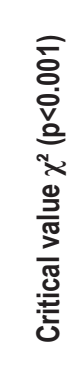 } \\
\hline & & 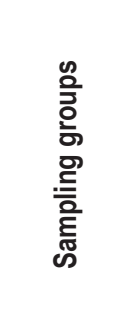 & 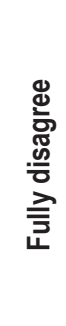 & 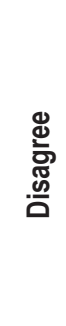 & 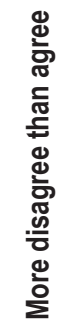 & 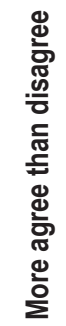 & ষ্ণ & 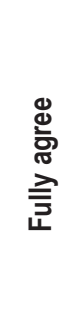 & 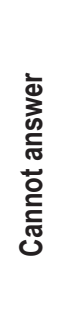 & & \\
\hline \multirow{2}{*}{$\begin{array}{l}1 . \\
2 .\end{array}$} & \multirow{2}{*}{$\begin{array}{l}\text { All people with } \\
\text { special needs } \\
\text { should be isolated }\end{array}$} & $\begin{array}{l}\text { First year } \\
\text { students }\end{array}$ & 18.0 & 34.0 & 27.7 & 12.5 & 4.2 & 0.6 & 3.0 & \multirow[b]{2}{*}{61.56} & \multirow[b]{2}{*}{22.46} \\
\hline & & $\begin{array}{c}\text { Senior } \\
\text { students }\end{array}$ & 13.3 & 25.0 & 30.5 & 21.2 & 4.0 & 6.0 & - & & \\
\hline \multirow[b]{2}{*}{4.} & \multirow{2}{*}{$\begin{array}{l}\text { I am ready to ac- } \\
\text { cept a person with } \\
\text { special needs as } \\
\text { a member of my } \\
\text { family }\end{array}$} & $\begin{array}{l}\text { First year } \\
\text { students }\end{array}$ & 9.6 & 10.0 & 33.5 & 30.0 & 8.4 & 7.5 & 1.0 & \multirow[b]{2}{*}{17.57} & \multirow[b]{2}{*}{22.46} \\
\hline & & $\begin{array}{l}\text { Senior } \\
\text { students }\end{array}$ & 7.3 & 21.2 & 37.0 & 24.5 & 6.0 & 3.4 & 0.6 & & \\
\hline \multirow[t]{2}{*}{5.} & \multirow{2}{*}{$\begin{array}{l}\text { I am ready for } \\
\text { communication } \\
\text { with people with } \\
\text { special needs }\end{array}$} & $\begin{array}{l}\text { First year } \\
\text { students }\end{array}$ & 1.0 & 4.2 & 10.0 & 30.0 & 30.0 & 23.0 & 1.8 & \multirow[b]{2}{*}{36.87} & \multirow[b]{2}{*}{22.46} \\
\hline & & $\begin{array}{c}\text { Senior } \\
\text { students }\end{array}$ & 5.4 & 8.6 & 16.0 & 33.0 & 26.5 & 10.5 & - & & \\
\hline \multirow{2}{*}{$\begin{array}{l}7 . \\
8 .\end{array}$} & \multirow{2}{*}{$\begin{array}{l}\text { People with special } \\
\text { needs and people } \\
\text { with no disabilities } \\
\text { should enjoy equal } \\
\text { rights }\end{array}$} & $\begin{array}{l}\text { First year } \\
\text { students }\end{array}$ & 4.8 & 6.2 & 7.4 & 13.2 & 31.5 & 35.0 & 1.8 & \multirow[b]{2}{*}{12.37} & \multirow[b]{2}{*}{22.46} \\
\hline & & $\begin{array}{l}\text { Senior } \\
\text { students }\end{array}$ & 2.0 & 10.0 & 14.0 & 14.0 & 27.6 & 32.4 & - & & \\
\hline
\end{tabular}




\begin{tabular}{|c|c|c|c|c|c|c|c|c|c|c|c|}
\hline \multirow{2}{*}{9.} & \multirow{2}{*}{$\begin{array}{l}\text { T would like to } \\
\text { become tolerant } \\
\text { towards other } \\
\text { people including } \\
\text { those with special }\end{array}$} & $\begin{array}{l}\text { First year } \\
\text { students }\end{array}$ & 3.6 & 4.8 & 3.6 & 19.9 & 33.8 & 30.1 & 4.2 & & \\
\hline & & $\begin{array}{c}\text { Senior } \\
\text { students }\end{array}$ & 2.6 & 6.6 & 12.0 & 21.2 & 37.0 & 20.6 & - & 28.14 & 22.46 \\
\hline
\end{tabular}

PROBLEMS

OF EDUCATION

IN THE $21^{\text {st }}$ CENTURY

Volume 43, 2012

The significant statistical differences in the groups of the first-year and senior students can be seen in the positions 1, 3, 5 on the table. However, the positions 2 and 4 depict no such differences.

Thus, $17.3 \%$ of the first-year students and $31.2 \%$ of the senior students believe, that people with special needs should be isolated; $45.9 \%$ of the first-year students are ready to accept a person with special needs as a member of their families, while this index drops down to $33.9 \%$ among the senior students; $86 \%$ of the first-year students are ready for communication with people with special needs, while only $70 \%$ of the senior students share this readiness; $79.7 \%$ and $74 \%$ of the first-year and senior students respectively agree, that people with special needs and those with no disabilities should enjoy equal rights. $83.8 \%$ and 78.8 of the first-year and senior students respectively express their wish to become more tolerant.

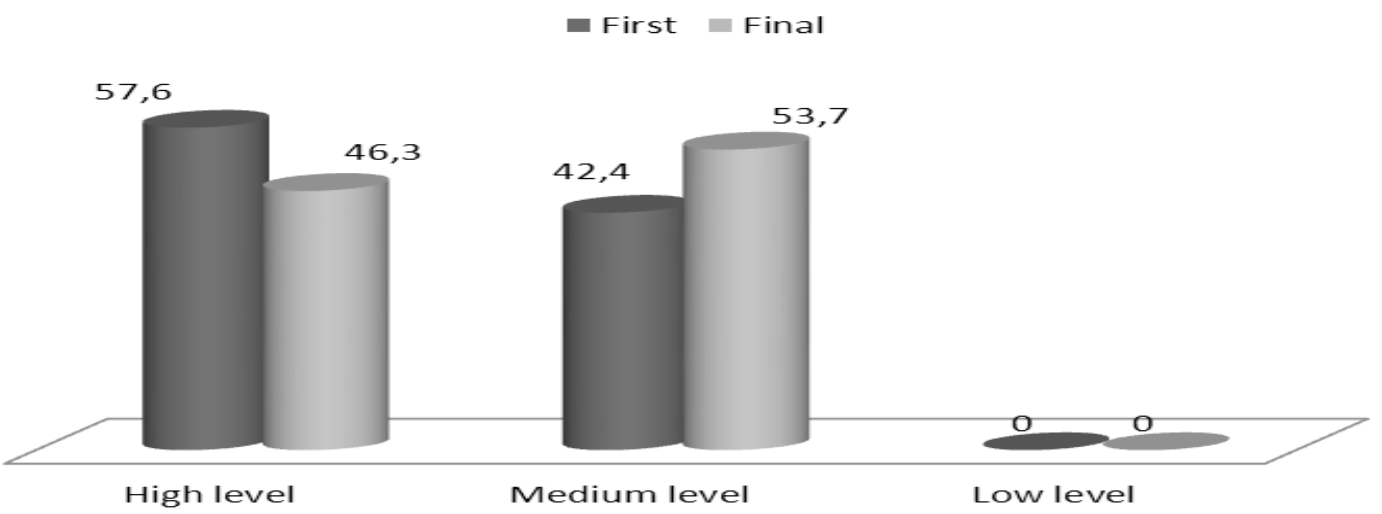

Figure 2: The comparative analysis of tolerance displayed in the communication by the first-year and senior students of the pedagogical specializations.

- First

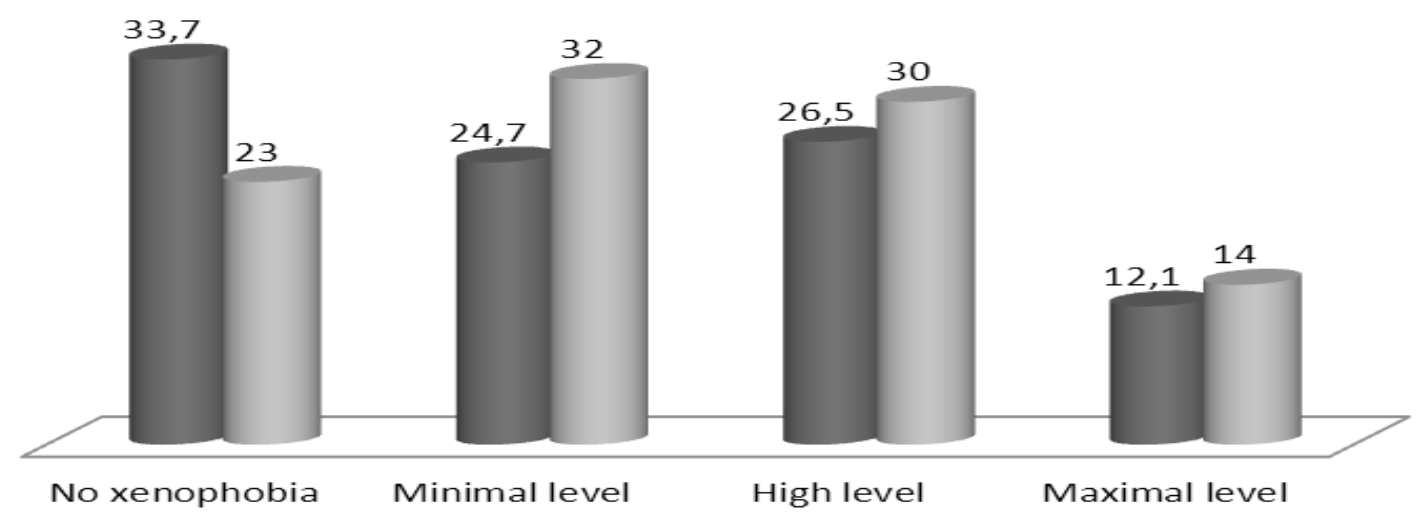

Figure 3: The comparative analysis of xenophobia displayed by the first-year and senior students of the pedagogical specializations. 
PROBLEMS

OF EDUCATION

IN THE $21^{\text {st }}$ CENTURY

volume 43,2012

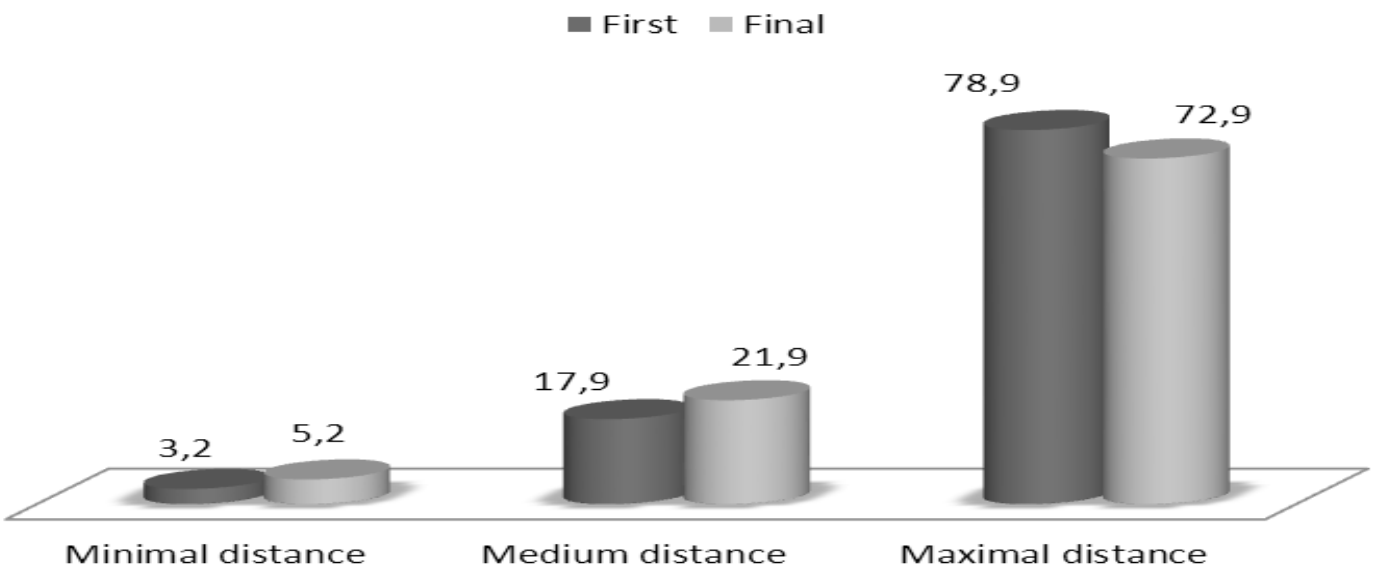

Figure 4: The comparative analysis of the social distance displayed by the firstyear and senior students of the pedagogical specializations.

\section{Discussion}

It becomes evident, that the neurotic extravert type prevails among the first-year and senior students of all specializations. This reveals, that prospective teachers do not have sufficient abilities to self-regulate their behaviour, avoid unaggressive behaviour towards another person, to face external stress which can affect his/her state of neuropsychic balance and to recover quickly the state of mental balance. It should be noted, that there is a tendency to an increase in quantitative indices of the neurotic (extrovert) type from the first to final years.

The introvert and stable respondents (stable introverts make $1.2 \%$ and $2 \%$ according to the sampling of the first and final years) are prone to follow rules and norms, be caring and attentive. On the contrary, the combination of an introvert and neurotic (20.5 and $23.1 \%$ according to the sampling of the first and final years) implies the tendency to show more pessimism, anxiety, reticence. The mixture of an extrovert and stability (4.8 and 3.3\% according to the sampling of the first and final years) adds such personal qualities as care, sociability and complaisance. The behaviour of an extrovert and neurotic (72.9 and $70.3 \%$ according to the sampling of the first and final years) is characterized by aggressiveness, impulsivity and excitability.

The obtained results permit to conclude that psychological stability of prospective teachers as their most important personal feature is not formed. The constancy of the neurotic state from the first to final years shows, that the content of pedagogical education has insufficient influence on the formation of stable types of personality.

The medium index of the motivated tendencies to "people-mindfulness" and "fear of rejection" significantly prevails among the first-year and senior students, which makes quite difficult to say anything about the possible behaviour or feelings of the respondents.

The dynamics of the increase of the "people-mindfulness" motive from the first to final years is also quite alerting. This dynamics sets thinking about the content of professional preparation and readiness of prospective pedagogues to work under the conditions of educational integration and personal qualities of a graduating student.

The general distinctive feature of all groups of both first and final years is a lack of quantitative indices, which characterize a low level of tolerance in the communication. Paradoxicality of the obtained results is a decrease in the high level indices.

The results, which reveal xenophobia towards children with special needs, give reasons 
to say, that there are differences in acceptance/rejection displayed by prospective teachers of "something different" which can be manifested through dysfunctions of psychic or/and physical development.

The obtained results, which reveal the extent of the social distance, enables to state, that the majority of the first-year and senior students have an inclination for significant remoteness from subjects of communication and interaction.

The analysis of the results shows, that despite the decrease in the maximum social distance to the final year towards people with special needs, remoteness remains at a high level among $72,9 \%$ of the senior students, that depicts an intolerant attitude towards this social group. Thus, most senior students show a higher level of remoteness towards subjects of the educational process, and their majority has the maximum level of remoteness.

The absence of statistically significant differences of the division of two empiric samplings of the studied tolerance aspects (see Table 2) shows, that the content of pedagogical education does not influence the formation of tolerance towards children with special needs. A research to define the optimal conditions for the formation of inclusive tolerance of prospective teachers as an important professional-pedagogical quality which guarantees professional competence should be conducted. Moreover, the content of pedagogical education as the preparation of prospective teachers to work with children with special needs under the conditions of inclusive education is an actual problem.

\section{Conclusions}

The formational level of inclusive tolerance (a tolerant attitude and the display of tolerant behaviour models towards psychophysically disabled children (with special needs) do not allow making a successful forecast for future pedagogues in their professional realization under the conditions of inclusive education. Obviously, intolerant behaviour, rejection of "something different" displayed in psychophysical disabilities, animosity and fear to those who do not resemble us may be seen in the behaviour of future pedagogues. Neither can it be stated, that the value aspect of inclusive tolerance is formed, where the values of a person, the values of freedom and rights, equality and acceptance of the right of choice of every person play a key role.

The actual content of pedagogical education revealed in the governmental standards of the preparation of specialists on the first stage of higher education and implemented through the content of the subjects of the course structures, is unfortunately an insufficient determinant to influence the formation of inclusive tolerance of future pedagogues and their successful professional activity under the conditions of inclusive education.

\section{References}

Асташкова, H. А. (Astashkova) (2002). Проблема воспитания толерантности в системе образовательных учреждений. Москва.

Байбородова, Л.В.(Baiborodova) (2001). Воспитание толерантности через деятельность и общение. Ярославский педагогический вестник, 2, 90-95.

Гершунский, Б. С. (Gershunskyi) (2002). Толерантность в системе ценностно-целевых приоритетов. Педагогика.

Гладкая, В. В. (Gladkaya) (2011). Специальная профессиональная компетентность. Кіраванне у адукацьіi, 6.

Грачева, Ю.И.(Gracheva)(2009). Воспитаниетолерантностистудентов вучебно-воспитательном проиессе технического вуза. Самара.

Желнович, О. В. (Zhelnovich) (2010). Воспитание толерантности студентов вуза. Новокузнецк. 
PROBLEMS

OF EDUCATION

IN THE $21^{\text {st }}$ CENTURY

Volume 43,2012

Змушко, А. M. (Zmushko) (2010). Интегрированное обучение и воспитание - приоритет развития специального образования. Адукацыя і выхаванне, 8 .

Касьянова, Е. И. (Kasianova) (2009). Социально-философские основания толерантности. УланУдэ.

Кривцова, Е. В. (Krivtsova) (2009). Толерантность личности в системе структурносодержательных характеристик иеенностного самоопределения. Москва.

Лекторский, В. А. (Lectorskyi) (1997). О толерантности, плюрализме и критицизме. Bonpocbl философии, 11.

Моргунова,М.А.(Morgunova)(2009).Развитиетолерантнойкультурыпедагогаобщеобразовательной икольл. Воронеж.

Николаева, Л. А. (Nikolaeva) (2007). Формирование коммуникативной толерантности студентов - будущих юристов (на примере университетского образования в России и Германии. Кемерово.

Панина,В.А.(Рanina)(2005). Развитиетолерантнойпозищиистудентоввпроцессепрофессиональной подготовки в университете. Краснодар.

Погодина, А. А. (Pogodina) (2006). Подготовка будущих педагогов к воспитанию толерантности у школьников. Ярославль.

Пчелинцева, И. Г. (Pchelintseva) (2006). Построение толерантной среды в образовательном пространстве высшего учебного заведения. Санкт-Петербург.

Соколов, В. М. (Sokolov) (2003). Толерантность: состояние и тенденции. Социологические исследования, 8 .

Солдатова, Г. У. (Soldatova) (2008). Психодиагностика толерантности личности. Москва.

Стрельцова, Е. A. (Streltsova) (2003). Диалоговая интерпретащия знания как средство воспитания толерантности у студентов. Волгоград.

Тарантей, В. П. (Tarantei) (2011). Межкультурное и региональное образование в современном обществе. Кіраванне ў адукаџыi, 3 .

Advised by Laima Railiene, University of Siauliai, Lithuania

Received: April 30, 2012

Accepted: June 04, 2012

\begin{tabular}{|ll} 
Vera V. Khitruk & PhD, Lecturer, Baranovichi State University, 21 Voikov Street, Baranovichi, \\
& Brest Region, 225404, Republic of Belarus \\
& E-mail: hvv64@tut.by \\
& Website: http://www.barsu.by/en/ \\
\hline Olga A. Ulianova & PhD, Lecturer, Baranovichi State University, 21 Voikov Street, Baranovichi, \\
& Brest Region, 225404, Republic of Belarus \\
& E-mail: ulianova@tut.by \\
& Website: http://www.barsu.by/en/
\end{tabular}

Vera V. Khitruk

Website: http://www.barsu.by/en/ 